\title{
Age does not determine influence: A consideration for children in ministerial service
}

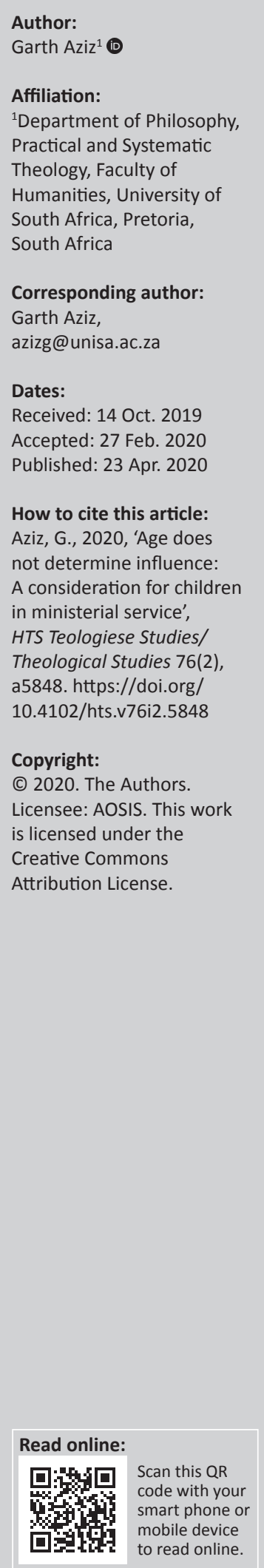

Leadership and areas of influence are often reserved for the adult community. The youth are mostly regarded as developing beings, with insufficient knowledge and experience to take on leadership roles where influence can be exercised. It is often considered - especially in the context of the church - that the youth do not have the capacity to lead, while evidence from society and research studies points to the contrary. The author of this article argues that the ability to influence does not depend on age or in an accumulation of experience. Instead, the ability of the youth to make a difference is attributed to their desire to do so. The author draws attention to why we need to focus on the youth and their ability to make a difference. The article presents an argument based on scriptural evidence and a theology of childhood as to why it is indeed possible and beneficial for the youth to exert their influence across various sectors of society.

Keywords: Youth; Children; Theologies of childhood; Childhood studies; Leadership; Individuation; Service; Skills development.

\section{Introduction}

There was a common saying during my childhood years that 'children should be seen and not heard'. The implication of this expression is that there is a place for children and youths; however, it is not in the conversations or in structures that favour adults. In addition, it implies that children do not have the necessary skill or knowledge to make constructive contributions in areas dominated by adults. In a way, the role, place and influence of the youth within society - and, more specifically the church - have been relegated to the back burner, because of their perceived inexperience and recklessness, as youths are deemed unable to make significant contributions. It is in the context of the church, specifically, that the area of youth leadership (where they are able to make the most significant contribution to change) remains problematic.

It is a common practice to suggest that leadership and influence are either natural traits in a person or acquired throughout life as a result of specific training that is aimed at expanding an individual's capacity for leadership and influence. As MacNeil (2006:28-29) argues, leadership includes the ability and authority to effectively lead people. The intention here is not to suggest ways of developing and training the youth for effective leadership. There are already many studies that have been conducted to suggest or address ways of adapting and applying 'adult' leadership theories to youth leadership development, or as a means of benefiting youth through leadership (MacNeil 2006; Rickets \& Rudd 2002). It is in this context that the current article recognises that the saying of Jesus in Matthew 20:16, that 'the last shall be first', has a significant bearing on the youth. It is understandable, therefore, that Christian leadership should not be dependent on the knowledge and experience which a person acquires solely by virtue of his or her maturity or the accumulation of years. Instead, in this article, I argue that the youth are indeed capable of assuming positions of leadership and have much to offer to the church and society, given their acceptance by Jesus Christ.

In this article, I will briefly establish the context by looking at the population of youths around the world, in Africa and South Africa, respectively, to show why it has become necessary to consider their influential role in leadership. Furthermore, I will use a biblical perspective to indicate how youth are validated in the Scriptures and specifically by Jesus Christ. I conclude with contemporary theoretical perspectives and studies on youth. The aim here is to argue that the youth are equally capable and worthy of assuming leadership roles in various areas of influence in the church and in fact that their involvement offers many benefits.

1.I use the term 'child" or 'children' in this article for continuity. I, however, use the terms 'child", 'older child", 'youth" and 'young adult' synonymously and interchangeably. These terms are conceptualised further in the article. 


\section{Youth in context}

In this section, I will be painting, with broad strokes, what the youth population looks like and what the composition of this population group means for countries such as South Africa. It is important to note that the phenomenon of a growing cohort of young people, who are both oppressed and marginalised, is not solely endemic to South Africa. The problem of youth marginalisation extends into the greater sub-Saharan Africa and other countries of the world.

\section{Youth in Africa}

The world's youth population exceeds 1.8 billion, with most youths coming from developing countries (United Nations Population Fund 2019). Nearly half of the world's youth live in sub-Saharan Africa (Gray 2018). Notably, in Africa, the median age is 18 years, while in South America it is 35 years (Bunge 2016:92-93; Omarjee 2018). Africa, which is the second largest and second most populous continent in the world, is estimated to have a population of 2.4 billion by 2050 .

Where most continents' populations have peaked, those of Africa and Asia are continuing to grow (United Nations Population 2015). It is predicted that by 2100, Africa will account for $48 \%$ of the world's youth below the age of 14 years (Meriam 2015; Mills 2019) and 42\% of those below the age of 24 years (Khokhar 2017). Currently, 41\% of Africa's population is below 15 years of age (Mills 2019; World Population Review 2019). This rate of population growth will cause 'Africa' to grow younger, while the 'rest of the world' ages (Mills 2019). Africa, as a developing continent, is home to some of the poorest countries in the world, and is plagued by problems of poverty, violence and failing governments (Gawanas 2009:150). In spite of its earnest pursuit of a human rights charter, this continent is no stranger to human rights violations (Bunge 2016:110; Gawanas 2009:137; Mubangizi 2007:97). Many of these violations are related to the youth of Africa.

Africa and the future influence of this continent are indeed dependent upon its youth, who can make a significant impact if they are treated as an asset, in the process of working towards growth and the creation of opportunities (Mills 2019; Omarjee 2018; United Nations Population Fund 2019). Interestingly, while the youth care about the world, they are unable to fully participate in society (Gray 2018) and are not given the attention they deserve (Bunge 2016:93). What further complicates the agency of the youth of Africa is that they are digitally connected to the world (Mills 2019), with their lifestyles and choices being influenced by those both near and far. The results of their connection to the world, the frustrations that are emblematic of a struggling context and the lack of opportunity for engagement are evident in movements such as the Arab Spring uprising of 2010 in the Middle East and the \#FeesMustFall movement in South Africa in 2015. Africa's youth are desperately crying out to be recognised and given opportunities for a better future.

\section{Youth in South Africa}

South Africa has a very young population, with more than $58 \%$ of its inhabitants below the age of 34 years (Stats SA 2012). In spite of the majority of the population being young, South Africa's society is invariably dominated by the influence of the adult community. The young people of this country have inherited a system of oppression, violence and poverty (Dames 2013:5ff.). South Africa's historic apartheid legacy, with its draconian policies and laws, has caused the majority of this country's youth (mainly black and mixed race Africans) to have limited or restricted access to socioeconomic resources (Burger, Louw \& Van der Watt 2010:62; Mubangizi \& Mubangizi 2005:278). The situation has indeed become desperate, with the poverty level in 2015 standing at $55.5 \%$, and approximate youth unemployment - which affects 3.3 million individuals - estimated at 38.2\% (Stats SA $2017,2018)$. In 2019 , the youth unemployment rate in this country is deemed to be $55.2 \%$, while young people account for $63.4 \%$ of the total number of unemployed (Stats SA 2019). Furthermore, the social context, along with definitions of the family, community and self, is ever shifting and morphing an occurrence that is further complicated by extreme violence and chemical substance abuse across our nation (Aziz 2014). The dawn of a new democratic South Africa in 1994 and 25 years of democracy have done little to help the youth of this country (National Youth Policy [NYP] 2015-2020:3).

The resultant reality that faces the many townships and subeconomic communities that were created during the forced removals under the Group Areas Act of 1950 in apartheid South Africa is that they continue to comprise mainly the mixed race and black African population. Forced removals under apartheid led to the creation of areas that are under conflict and highly volatile, where communities experience high unemployment, a shortage of housing, overcrowding, systemic violent crime and a general lack of access to the most basic socio-economic rights as defined by the Human Rights Bill in the South African constitution (RSA 1996:5-20). Arguably, the existence of violent crime in this country is because of the population's limited access to socio-economic resources, such as meaningful schooling and employment. While many agencies have attempted to assist these specific population groups in accessing socio-economic resources, large segments of the population continue to have only limited access - in particular, the youth of South Africa.

It is difficult to determine what would be in the interest of youth, because of their low representation in the South African parliament: in 2018, only eight youths under the age of 35 years served as members of parliament, while the median age of parliamentarians was 54 years (Parliamentary Monitoring Group 2018). This figure seems consistent with the median age of church leaders: in a study conducted in the United States, it was found that the cohort of pastors is an ageing one (Brumley 2017), with one in seven pastors below 40 years of age, and a median age of 54 (Shellnut 2017). These findings were documented by the Barna Group, which researched the state of pastors in America (Shellnut 2017). 
A particular study in the South African context, which dealt with youth pastors, found that a person or minister is best suited for the youth ministry when he or she is below the age of 40 and preferably in their mid-20s to mid-30s. Such an individual is ideally suited to be in a leadership position in the youth ministry because of his or her relevance, the ability to relate to young people and his or her level of life experience (resulting in maturity, or the lack thereof) (Aziz, Nel \& Davis 2017:5).

This section has highlighted the extreme situation and context facing the youth. Not only do the youth have to fight against historic and systemic injustices, limited access to socio-economic resources, high unemployment, poverty and violence, they also have to contend with a limited space in which their voices and concerns can be heard, because of such spaces of influence being occupied by an ageing adult community.

\section{Conceptualising youth}

Much has been discussed about youth, without clearly conceptualising what is meant by the term 'youth'. In this section, I will briefly supply a contemporary understanding of youth. Defining 'youth' remains a difficult endeavour, which is further problematised by the fact that it is not the youth who constructed the definition and meaning of the term, but adults (Grobbelaar 2016:60). When discussing youth, I recognise my bias and limited insight into this important group of people, as I approach the topic from the perspective of an adult. When discussing youth, I always use the term as being inclusive of children, young people and young adults, as defined by the national policy of South Africa, which sets the maximum age of a 'youth' at 35 (NYP 2015-2020). This inclusive categorisation is generally accepted in the fields of youth work and youth ministry, which are subfields of youth work (Nel 2000:8). When Bunge (2001:1) discusses children, she does not peg an age to them; instead, she includes the challenges facing both younger and older children, such as abuse, depression and teenage pregnancy. Defining youth in a South African context is further complicated by the many cultural and religious expressions that are obtained locally. To classify youth based on age alone becomes a problematic endeavour. It may be more appropriate to cite Santrock (1990) when addressing the parameters of youth as beginning 'in biology and ending in culture' (see also Clark 2001:45). The period that is associated with youth is not limited to a physical time frame, but it is also a social construct (Grobbelaar 2016:56). Interestingly, Counted (2016) defines 'youth' as a period of transition and revelation, as this is often the time when God reveals himself to young people. An encompassing definition therefore acknowledges the complexities of youth, irrespective of circumstances, and also recognises that children - young and old - are fully human already and may serve as models of faith (Bunge 2001:18-19; 2012a:65). To avoid any oversimplification of the journeys of youth, it is prudent at this stage to only identify the various fields in research which regard the youth, namely identity, individuation, family matters and context, to mention a few.
Here, the focus is solely on one field, namely individuation, as this has a direct bearing on the influence young people exert.

\section{Individuation}

Discussing matters of identity, identity formation and identity discovery with respect to the youth is beyond the scope of the current article. It nevertheless seems prudent to briefly introduce the topic of individuation, which should be the aim of every parent and youth worker ( $\mathrm{Nel} 2000: 30)$. It is generally accepted that the passage of youth, especially the developmental years, is characterised by turmoil, confusion and numerous life-changing decisions. It is a time when the youth are faced with, and ask, existential questions such as 'Who am I?', 'What am I?' and 'Who do I belong to?' It is a time of identity shaping and discovery, a meeting with God. This period of transition is often used as an excuse to justify the marginalisation and romanticising of youth. The prevailing argument is that young people are inexperienced, they do not know what they want and they have nothing positive or substantial to offer. Yet, it is during this period that youths seek to find their place in the world and to define their contribution to society - a process called individuation. It is important to see this process as more than a mere separation from their primary caregivers, rather as an important part in shaping the youth for civic duty.

The Mail \& Guardian (2018) annually publishes a feature on the top 200 youths under the age of 35, who are making a considerable change and adding value to society and/or their country of origin. Examples of such remarkable young people include Greta Thunberg from Sweden, who at the age of 16 has been nominated for the Nobel Peace Prize in environmental affairs (Carrington 2019). Sibongiseni Ngcobo, at the age of 23, is currently the youngest member of parliament serving in South Africa (Makatile 2019). At age 20, Leroy Mwasaru from Kenya is the youngest CEO in Africa (Forbes Africa 2018). Zareef Minty, aged 24 years, is the youngest CEO in South Africa and has been included in the Top 200 list of young and influential South Africans; he has published a book and is a lawyer, motivational speaker and radio host (Forbes Africa 2018).

As indicated, age is no criterion for being influential in the world or in one's society. Kouzes and Posner (2008) argue that age is not (and never should be) a criterion for leadership, or the ability to influence and make a difference. In fact, they claim that youth could be a catalyst for change and influence, citing many examples where young people have made a considerable impact on their respective societies and countries. Ironically, youth leadership and influence do not extend to the church or matters of faith (Breed 2016:276). Grobbelaar (2016:77) states that one of the biggest challenges to developing adequate approaches to child theologies is the abuse of power by the adult community, which silences and removes children from worship services and church meetings. In effect, the result of the abuse of such power being inflicted on children is that it limits their self-actualisation and thereby creates a largely silent generation (Grobbelaar 2016:77). 


\section{Youth in the Bible}

When discussing young people who are mentioned in the Bible, it behoves one to tread carefully to avoid being anachronistic and reading too much of our present context into a time and culture that are both distant from and foreign to the current state of affairs. Without being prescriptive, the Bible continues to be a vital component of, and source in, informing views on children and youths (Bunge 2012a:59, 2016:102). As cautioned by Nel (2000:8-9), the Bible can by no means be prescriptive or be used as a textbook when building arguments to sway any discussion on the youth. Nonetheless, as Bunge (2012a:59) notes, the Bible speaks not only about children but also about the (often complex) relationships between adults and children. In this section, I will once again use broad brush strokes to highlight sections in the Bible where the youth are identified, given worth and value, and afforded specific functions and privileges of being instruments used by God. This applies to the Old Testament, the New Testament and especially to Jesus Christ, at a time when children were considered to belong to the lowliest echelons in society (Bunge 2016:102).

\section{Old Testament}

It is important to begin right at the start, in the Old Testament, where children are considered a heritage and blessing from God (Ps 127:3-5; Gn 33:5) (Bunge 2016:103; Nel 2000). It indeed does make sense when considering that God is involved in the conception, birth and lives of children $(\mathrm{Gn}$ 21:17; Ps 144:13; 115:14-15), that they would matter to God. Children, according to Gundry-Volf (2001:34), have a significant place and role in the Old Testament. Their inclusion in religious ceremonies is evident: they are not only a part of the religious community but also instruments in God 'coming' to his people (Deut 6; 1 Sam 1:4; 2 Ki 5:2-3; Sam 16-17) (Bunge 2016:103). There are also cases where youths act as agents of social change, becoming leaders and rulers holding important positions, where entire households and nations are dependent on their rule (Bunge 2016:103). One sees such cases of leadership when David, a shepherd boy, becomes the king of a nation (2 Sam 16-17). Furthermore, Daniel (Dan 1:8) becomes second in command in Babylon under King Nebuchadnezzar, and Joseph becomes the righthand man of Pharaoh (Gn 41), while both are still in their youth. It is therefore important to recognise that children were not only divine gifts of God but also recipients of 'the sign of the covenant' (Gundry-Volf 2001:34) and bearers of theological truths who often brought about change and liberation for God's people (Grobbelaar 2016:45).

\section{New Testament}

Gundry-Volf (2001:36-59) gives an in-depth view and discussion of children in the New Testament, where they are recipients and models in respect of the reign of God and entering God's kingdom. A youth is present at the first disciplinary act in the church (Ac 5), while children also worship together with their parents (Ac 21:5) and even have the gift of prophecy (Ac 21:9).
Jesus places great importance on children (Mt 19:13-34; Mk 10:13-16; Lk 18:2-5; Mk 9:36-37; Lk 9:47-48; Mt 18:10; Mt 18:14) and identifies them as the greatest in the kingdom and the plumbline for inheriting the kingdom of God (Mt 18:1-5) (Bunge 2016:104). Jesus also raises children from the dead (Mt 9:22-26) and cautions against the abuse of children, emphasising our duty to protect them (Mt 18:6-7). Gundry-Volf (2001:40) defines the childlike characteristics in question as:

$[R]$ linquishing the-Law-as-the-basis-for-entering-God's-reign [...] by asserting instead [a]simple dependence [on] God's mercy. Entering the reign of God 'as a child' thus seems to involve both a certain status - actual dependence on God - and a corresponding quality - trust - that are both 'childlike'. (p. 40)

\section{Theoretical approaches to youth studies}

Childhood and youth studies, according to Bunge (2012b:3), take the perceptions and behaviours of adults towards children and also children's vulnerabilities, perceptions, experiences and agency seriously. Experience, according to Bunge (2016:109), remains a significant factor in theological studies. The experience of children and theological reflection on their experience should also have a significant bearing on the development of children's theologies and on the process of designing programmes aimed at infants and youths. By reflecting on, and including, the experiences of children, we are inviting them as active participants to be part of the theological and practical endeavours that affect them or surround them. Children, through their experiences and agency, can thus transform fundamental social norms. It is not enough to create inclusive spaces for them: we should allow children to transform their own places. One must tread carefully at this stage so as not to further create a biased approach towards children and youth by further creating and solidifying the very different natures and realities of children and youth. The focus is on creating an inclusive conversation of all those not considered to be adult. The theoretical approach, therefore, looks at childhood studies knowing that it is inclusive of all those not considered adult.

\section{Waves of childhood studies}

The inclusion of children in research is clearly visible from the 'waves of childhood studies' in recent years. While this article does not discuss the origins and evolution of childhood studies, it is prudent to recognise what this domain has achieved in research. The first wave (1980s) recognised that children are fully human in their own right and are not merely beings who are transforming into adults. In other words, children are not adults in the making. They have their own agency and voice (Grobbelaar 2016:59). The second wave (1990s) recognised that children can be active participants in research. However, while children may be involved in research, they do not inform the basic questions of a research undertaking. The notion is that children are able to be self-interpreters as well as interpreters of others. 
In other words, they are able to extend themselves to consider people other than themselves. The third wave, during the 2000s, recognises and includes children as active agents in research and as equal to adults in this endeavour. Children's distinctiveness and experiences are taken into consideration as they 'transform basic scholarly and societal structures' (Wall 2012:138).

\section{Theologies of childhood}

It is encouraging to note that although there has been little critical reflection on children, there is now an increased interest and growth in the literature pertaining to theologies on childhood, especially in the developing world (Bunge 2001:2; eds. Grobbelaar \& Breed 2016a, 2016b; Wall 2012:135; Weber \& De Beer 2017). After all, 'the task of "theologies of childhood" is to provide sophisticated understandings of children and childhood, and our obligations to children themselves' (Bunge 2016:97).

Bunge (2012a:62), who is an expert and leading researcher in the field of children and childhood studies, explains that it is important to build good theologies of childhood. Although children are vulnerable, they remain agents of social change and models of faith. Bunge (2009:4-7) mentions four perspectives that should influence one's theology and approach to children and youth.

Firstly, and most basically, children are vulnerable beings. Arguably, they are the most vulnerable in society (Breed 2016:283; Bunge 2009:4-7) because they are most dependent on the provision and protection of others. In this sense, children are to be protected and provided for, while they remain dependent beings. Secondly, 'the Bible depicts children as gifts of God and sources of joy who are fully human and made in the image of God, therefore parents and other caring adults are to respect them, enjoy them, and be grateful for them' (Bunge 2009:4-7, 2016:103; Nel 2000).

A third dimension of the view of children in the Bible and the Christian tradition is that they are also developing beings, sinful creatures and moral agents in need of instruction and guidance, therefore parents are to nurture the faith of children and help them use their gifts and talents to love and serve others, and contribute to the common good (Bunge 2009:4-7).

The fourth perspective declares that the Bible also depicts children as models of faith for adults, as sources of revelation and as representatives of Jesus; therefore, adults should listen to children and learn from them (Bunge 2001:18-19, 2009:4-7, 2012a:65).

Children are therefore not only used as an example of the type of person who will inherit the kingdom of God but also as models of faith and revelation (Bunge 2009:7, 2016:100). Furthermore, children's relentless pursuit and quest for answers shed significant light on the fact that facts and situations need to be questioned. They generally are not interested in positions of status or climbing the corporate ladder, so for them, position is not about power or promotion.

\section{The value and influence of youth in ministerial service}

Understanding what ministerial service is fundamental to allowing youth into influential circles is of prime importance. Ministerial service, in the article, refers to any form of action within the church. This approach is based on the principle of the priesthood of all believers where each person not only has the capacity or ability to lead and act but also has a capacity equal to the minister for God irrespective of age, gender, official or ordained capacity in the church. Ministerial service, therefore, is not an official ordained leadership function but is also not restricted from official ordained leadership functions.

Gundry-Volf (2001:47-48) emphasises that children 'who know nothing' can also 'know divine secrets' and reveal the identity of Jesus. As previously mentioned, Bunge (2012a:62) highlights the significant role children can play in working towards social change and being models of faith. Bunge (2012a:62) therefore seeks to raise awareness of the fact that children can indeed teach others, while the adult community can learn from them. The opinions of Weber and De Beer (2017) are equally valid when they state that children should be more than just a part of the community, but rather 'collaborators and co-researchers in the community', as their opinions have value and they can make considerable contributions to leadership and change in the church (GundryVolf 2001):

Children are not only subordinate but sharers with adults in the life of faith; they are not only to be formed but to be imitated; they are not only ignorant but capable of receiving spiritual insight; they are not 'just' children but representatives of Christ. What makes that challenge so difficult is that it would entail changing not only how adults relate to children but how we conceive our social world. Jesus did not just teach how to make an adult world kinder and more just for children; he taught the arrival of a social world in part defined by and organized around children. He cast judgement on the adult world because it is not the child's world. He made a disciple dependent on inhabiting this 'small world'. He invited the children to come to him not so that he might initiate them into the adult realm but so that they might receive what is properly theirs - the reign of God. (p. 60)

Social norms should therefore not be based solely on the experiences of adults. Instead, the experience of children should be taken seriously, and they should be allowed to transform social norms (Wall 2012:136). Bunge (2012a; cf. Bunge 2016:104; Grobbelaar 2016:49) recognises that there have always been theologians (albeit few in number) who challenge adults:

$[T]$ o be receptive to the lessons and wisdom that children can offer them, to honor children's questions and insights, and to recognise that children can positively influence the community and the moral and spiritual lives of adults. (p. 67) 
Bunge (2016:101) recaps Miller-McLemore's statement that children must be 'fully respected as persons, valued as gifts, and viewed as agents'. Children should be 'fully integrated in the ministry of the church' and be allowed to influence and shape the ministry and practice of the church, according to Breed (2016:276). Interestingly, Breed (2016:283-284) argues that service in church does not hinge on what we are able to do for the church, but what God is able to do through us; thus, 'ministry should not be seen as something required of a human being but as the ministry of the triune God'. In this sense, Breed (2016:285-286, 291) argues that children should be part of the service and ministry of God, as they are exactly where God has placed them and where he wants them. Children, therefore, should be consulted not only as ministry partners but also as the relevant voices of those who are continuously marginalised (i.e., children) (Grobbelaar 2016:59; Nel 2016:185-186). In doing so, more relevant programmes can be developed, as these will be informed by those who will ultimately be affected by them.

Furthermore, involving children in the leadership and service of the church minimises the risk of them leaving the church; it helps them discover their true identity and uniqueness in God; it equips them with respect to their vocational choices (individuation); it creates a sense of belonging to something that is bigger than themselves; children learn to appreciate diversity; and they get to see God working in their own lives and in the lives of others (Breed 2016:290-298). When God wanted to change the world, he often used children (Grobbelaar 2016:46)

\section{Limitations and further research}

There are two areas in the research article that deserve attention; however, because of the nature and space of the article, they were not entered into the discussion. The purpose, therefore, is to merely list these as limitations and future research opportunities without entering into much discussion,

The first area is the role of the adult community in creating spaces and providing skills development for youth in order that they may effectively influence and be heard. The primary focus of the article is on the agency, influence and challenges of the youth because of their perceived lack of life experience and not on the actions of adults. However, creating space and providing skills development require a certain response from the adult community whereby they would recognise humility and the release of power structures in order that the youth may thrive. The adult response, in creating spaces for the child, also has to recognise the complexities of children and youth and their ever-evolving realities in light of their developmental journey.

The second area for further research involves assisting the youth where their perceived lack of experience does not allow for emotional moderation when their voices are not heard and may be perceived as rejection. This remains an assumption on the reactions of the youth and may require an empirical component to actually collect evidence on how this perceived problem does in fact affect them and how they might respond.

\section{Conclusion}

This article has attempted to conceptualise 'youth' as an inclusive category comprising young children, older children, teenagers and young adults. I recognise that this conceptualisation is a cultural reality that makes a definition problematic. Conceptualising youth is further problematised as it remains in the domain of the adult community, with little input from the actual population under consideration. This control by the adult community is indeed an area of concern, as the vast majority of the world's population consists of youth - a situation that is no different in Africa and South Africa, specifically. The majority of the population is indeed young; therefore, it requires a concerted and intentional effort on the part of the adult community to place the youth's significance centre stage. That would imply a power shift and require the adult community to relinquish control to the youth.

It is essential to recognise that the youth's ability to influence their peers and others is entrenched in their humanity, rather than in their age or level of experience. This affirmation of their humanity is evident in the scriptures and the actions of Jesus Christ, and has since been developed across various academic studies. The current article also addressed the value youths add, through their influence, to various spheres and organisations within society, and even the church. It is thus vital to not only recognise but also affirm their humanity and influence, the value they bring to the various sectors of society and also to grant them opportunities to let them add their voice and influence, so that this group is not relegated to a position where their worth remains a purely theoretical construct.

While this article does not address the various places or means to allow the youth to exercise their influence and make their voices heard, it has indeed sought to raise awareness that there should be places for, and means of, exerting their influence. The shortcoming of this article therefore presents a further opportunity for research into establishing a place for, and creating the means to allow, the youth to be both seen and heard.

\section{Acknowledgements Competing interests}

The author declares that he has no financial or personal relationships which may have inappropriately influenced him in writing this article.

\section{Author's contributions}

G.A. is the sole author of this article. 


\section{Ethical considerations}

This article followed all ethical standards for a research without direct contact with human or animal subjects.

\section{Funding information}

This research received no specific grant from any funding agency in the public, commercial or not-for-profit sectors.

\section{Data availability statement}

Data sharing is not applicable to this article as no new data were created or analysed during this study.

\section{Disclaimer}

The views and opinions expressed in this article are those of the authors and do not necessarily reflect the official policy or position of any affiliated agency of the authors.

\section{References}

Aziz, G., 2014, 'Youth ministry as an agent for reconciliation in the breakdown of coloured families from urban communities in Cape Town: A post-apartheid perspective', The South African Baptist Journal of Theology 23, 231-241.

Aziz, G., Nel, M. \& Davis, R., 2017, 'The career youth pastor: A contemporary reflection', HTS Teologiese Studies/Theological Studies 73(2), a3856. https://doi. org/10.4102/hts.v73i2.3856

Breed, G., 2016, 'Welcoming children to the diakonia of the congregation', in J. Grobbelaar \& G. Breed (eds.), Theologies of childhood and the children of Africa, pp. 274-300, AOSIS, Cape Town. https://doi.org/10.4102/aosis.2016.tcca02.09

Brumley, J., 2017, 'American pastors are older, and getting older than ever', Baptist News Global, 2 March, viewed 04 August 2019, from https://baptistnews.com/ article/american-pastors-are-older-and-getting-older-than-ever/\#.XUXKn_Izapp.

Bunge, M.J., 2001, 'Introduction', in M.J. Bunge (ed.), The child in Christian thought, pp. 1-28, Eerdmans, Grand Rapids, MI.

Bunge, M.J., 2009, 'Biblical and theological perspectives: Resources for raising children in the faith', Lutheran Partners 25(July/August), 4

Bunge, M.J., 2012a, 'Christian understandings of children: Central biblical themes and sources', in M.J. Bunge (ed.), Children, adults, and shared responsibilities, pp. 59-78, Cambridge University Press, Cambridge.

Bunge, M.J., 2012b, 'Introduction', in M.J. Bunge (ed.), Children, adults, and shared responsibilities, pp. 1-18, Cambridge University Press, Cambridge.

Bunge, M.J., 2016, 'Task, sources and significance of theologies of childhood', in J. Grobbelaar \& G. Breed (eds.), Theologies of childhood and the children of Africa, pp. 92-112, AOSIS, Cape Town. https://doi.org/10.4102/aosis.2016

Burger, R., Louw, M. \& Van der Watt, C., 2010, 'The challenge of poverty and social exclusion in post-apartheid South Africa: Considering the potential role of religious groups', in I. Swart, H. Rocher, S. Green \& J. Erasmus (eds.), Religion and social development in post-apartheid South Africa, pp. 61-74, SunPress, Cape Town.

Carrington, D., 2019, 'Greta Thunberg nominated for Nobel Peace Prize', The Guardian 14 March, viewed 6 August 2019, from https://www.theguardian.com/ world/2019/mar/14/greta-thunberg-nominated-nobel-peace-prize.

Clark, C., 2001, 'The changing face of adolescence: A theological view of human development', in K.C. Dean, C. Clark \& D. Rahn (eds.), Starting right: Thinking theologically about youth ministry, pp. 41-61, Zondervan, Grand Rapids, MI.

Counted, V., 2016, 'Missionising youth identity crisis: Towards a missional hermeneutic of coping in youth ministry practice', Missionalia 44(1), 85-102. https://doi. of coping in youth mini
org/10.7832/44-1-141

Dames, G.E., 2013, 'Knowing, believing, living in Africa: A practical theology perspective of the past, present and future', HTS Teologiese Studies/Theological Studies 69(1), Art. \#1260, 1-9. https://doi.org/10.4102/hts.v69i1.1260

Forbes Africa, 2018, 'Under 30 business', Forbes Africa, 4 June, viewed 04 June 2018 from https://www.forbesafrica.com/30-under-30/2018/06/04/under-30-business/.

Gawanas, B., 2009, 'The African Union: Concepts and implementation mechanisms relating to human rights', in A. Bösl \& J. Diescho (eds.), Human rights in Africa, pp. 135-163, MacMillan, Windhoek.

Gray, A., 2018, 'What you need to know about the world's youth, in 7 charts', viewed 20 May 2019, from https://www.weforum.org/agenda/2018/08/what-you-needto-know-about-the-worlds-young-people-in-7-charts/.

Grobbelaar, J., 2016, 'Doing child theology: History and methodology', in J. Grobbelaar \& G. Breed (eds.), Welcoming Africa's children - Theological and ministry perspectives, pp. 42-87, AOSIS, Cape Town. https://doi.org/10.4102/aosis.2016. waccs 13.02
Grobbelaar, J. \& Breed, G. (eds.), 2016a, Theologies of childhood and the children of Africa, AOSIS, Cape Town.

Grobbelaar, J. \& Breed, G. (eds.), 2016b, Welcoming Africa's children - Theological and ministry perspectives, AOSIS, Cape Town.

Gundry-Volf, J.M., 2001, 'The least and the greatest: Children in the New Testament', in M.J. Bunge (ed.), The child in Christian thought, pp. 29-60, Eerdmans, Grand Rapids, MI.

Khokhar, T., 2017, 'How is the world's youth population changing?', viewed 20 May 2019 from https://blogs.worldbank.org/opendata/chart-how-worlds-youth-populationchanging.

Kouzes, J.M. \& Posner, B.Z., 2008, The student leadership challenge: Five practices for exemplary leaders, Jossey-Bass, San Francisco, CA.

MacNeil, C.A., 2006, 'Bridging generations: Applying "adult" leadership theories to youth leadership development', New Directions for Youth Development 109, 27-43. https://doi.org/10.1002/yd

Mail \& Guardian, 2018, '200 young South Africans', viewed 06 August 2019, from https://200youngsouthafricans.co.za/.

Makatile, D., 2019, 'Youngest MP Sibongiseni Ngcobo has much to do', IOL, 28 May, viewed 06 August 2019, from https://www.iol.co.za/sundayindependent/ youngest-mp-sibongiseni-ngcobo-has-much-to-do-24250899.

Meriam, M., 2015, 'The young continent', viewed 20 May 2019, from https://www. economist.com/briefing/2015/12/12/the-young-continent.

Mills, G., 2019, 'Youth is Africa's prime challenge - But it could be an asset', viewed 20 May 2019, from https://mg.co.za/article/2019-01-11-00-youth-is-africasprime-challenge-but-it-could-bean-asset.

Mubangizi, J.C., 2007, 'The protection and enforcement of socio-economic rights in Africa: Lessons from the South African experience', African Foundation for International Law 15(1), 87-106. https://doi.org/10.1163/22116176-90000040

Mubangizi, J.C. \& Mubangizi, B.C., 2005, 'Poverty, human rights law and socioeconomic realities in South Africa', Development South Africa 22(2), 277-290. https://doi.org/10.1080/03768350500163311

National Youth Policy, 2015-2020, viewed 14 March 2019, from http://www. thepresidency.gov.za/MediaLib/Downloads/Downloads/NYP\%20Policy\%20 $2020 \% 20$ Report.pdf.

Nel, M., 2000, Youth ministry: An inclusive congregational approach, Malan Nel, Pretoria.

Nel, M., 2016, 'Integrating children in the life and ministry of faith communities', in J. Grobbelaar \& G. Breed (eds.), Welcoming Africa's children - Theological and ministry perspectives, pp. 164-192, AOSIS, Cape Town. https://doi.org/10.4102/ aosis.2016.waccs13.05

Omarjee, L., 2018, 'Beat poverty by investing in young people - Bill and Melinda Gates', Fin24, 18 September, viewed 14 July 2019, from https://www.fin24.com/ Economy/beat-poverty-by-investing-in-young-people-bill-and-melindagates-20180918.

Parliamentary Monitoring Group, 2018, 'Youth in parliament 2018', viewed 04 August 2019, from https://pmg.org.za/page/Youth\%20in\%20Parliament\%202018.

Republic of South Africa (RSA), 1996, Constitution of the Republic of South Africa, Act 108 of 1996, viewed 15 August 2019, from http://www.justice.gov.za/legislation/ constitution/SAConstitution-web-eng.pdf.

Rickets, J.C. \& Rudd, R.D., 2002, 'A comprehensive education model to train, teach and develop leadership in youth', Journal of Career and Technical Education 19(1), 7-17. https://doi.org/10.21061/jcte.v19i1.655

Santrock, J.W., 1990, Adolescence, 4th edn., William C. Brown, Dubuque, IA.

Shellnut, K., 2017, 'Only 1 in 7 pastors is under 40', Christianity Today International January 26, viewed 04 August 2019, from https://www.christianitytoday.com/ news/2017/january/only-1-in-7-senior-pastors-is-under-40-barna.html.

Statistics South Africa (Stats SA), 2012, Census 2011: Census in brief, Statistics South Africa, Pretoria, viewed 01 July 2019, from http://www.statssa.gov.za/census/ census_2011/census_products/Census_2011_Census_in_brief.pdf.

Statistics South Africa (Stats SA), 2017, Poverty trends in South Africa: An examination of absolute poverty between 2006 and 2015, Statistics South Africa, Pretoria.

Statistics South Africa (Stats SA), 2018, Youth unemployment still high in Q1:2018, Statistics South Africa, Pretoria, viewed 04 August 2019, from http://www.statssa. gov.za/?p=11129.

Statistics South Africa (Stats SA), 2019, Statistical release P0211: Quarterly Labour Force Survey, Quarter 1: 2019, Statistics South Africa, Pretoria, viewed 04 August 2019, from http://www.statssa.gov.za/publications/P0211/P02111stQuarter 2019, from

United Nations Population, 2015, 'Youth population trends and sustainable development', viewed 20 May 2019, from https://www.un.org/en/development/ desa/population/publications/pdf/popfacts/PopFacts_2015-1.pdf.

United Nations Population Fund, 2019, Youth participation and leadership, viewed 20 May 2019, from https://www.unfpa.org/youth-particpation-leadership.

Wall, J., 2012, 'Imagining childism: How childhood should transform religious ethics', in M.J. Bunge (ed.), Children, adults, and shared responsibilities, pp. 135-151, Cambridge University Press, Cambridge.

Weber, S. \& De Beer, S., 2017, 'Erratum: Doing theology with children in a South African context: Children as collaborators in intergenerational ministry', HTS Teologiese Studies/Theological Studies 72(1), a3572. https://doi.org/10.4102/hts. v72i1.3572-01

World Population Review, 2019, Africa population 2019, viewed 20 May 2019, from http://worldpopulationreview.com/continents/Africa-population/. 